\title{
Outorga do Prêmio "Moinho Santista" ao Professor Dr. Miguel Reale.
}

Mais uma vez tem esta Revista a satisfação de registrar, como honroso acontecimento para a história acadêmica, a outorga do Prêmio "Moinho Santista" de Ciências Jurídicas e Sociais a um de seus eminentes mestres, Prof. Dr. Miguel Reale.

Reuniu-se o grande juri da "Fundação Moinho Santista" para decidir a entrega do prêmio, no salão nobre do palácio da justiça, sob a presidência do desembargador Euclides Custódio da Silveira, presidente do Tribunal de Justiça do Estado de São Paulo; além do presidente da Fundação, Prof. Dr. Jorge Americano, estiveram presentes à reunião o vice-presidente do Supremo Tribunal Federal, Ministro Luís Galloti, reitores de universidades, dirigentes de entidades científicas e culturais.

Acatando as recomendações da Comissão Especial, o Grande Juri atribuíu o prêmio em Ciências Jurídicas e Sociais, na primeira categoria, ao Professor Dr. Miguel Reale e na segunda ao Dr. Gilberto Freire.

No salão nobre desta Faculdade, a 30 de setembro de 1964, em sessão solene presidida pelo Magnífico Reitor da Universidade de São Paulo, Prof. Dr. Gama e Silva, realizou-se a entrega do prêmio aos laureados.

Aberta a sessão, foi professor Miguel Reale introduzido no recinto por Dr. Alfredo Buzaid, sendo calorosamente recebido e saudado, em nome da Fundação, pelo Prof. Dr. Ernesto Leme, Secretário da Justiça do Estado e, em nome da Congregação dos Professôres, pelo Prof. Dr. Alfredo Buzaid. 
Recebeu também carinhosa homenagem de seus alunos, saudando-o, em nome dos colegas, o bacharelando Celso Lafer.

Agradecendo o prêmio e as homenagens recebidas, prof. Reale, em eloqüentes palavras, evidenciou uma vez mais seu entranhado amor à Faculdade, ao estudo e ao Direito.

\section{Saudação do Prof. Dr. Ernesto Leme.}

Cabe pela segunda vez à Faculdade de Direito de São Paulo recolher o Prêmio "Moinho Santista", no setor das ciências jurídicas. Com êle se coroou, em 1958, a atividade científica do professor Waldemar Martins Ferreira, o mestre mais eminente de sua geração no campo do Direito Comercial; sagra-se com êle, no dia de hoje, a vossa obra de pensador e de jurista, ao mesmo tempo que se premeia, nas ciências sociais em geral, o senhor Gilberto de Mello Freyre, cujo merecimento intelectual já recebeu, no país e no estrangeiro, a consagração definitiva.

Ao percorrer ainda agora a vossa extensa bibliografia, em que se deparam versados os temas mais diversos, na esfera da filosofia, do direito, da economia e da história, os meus olhos se voltam para o passado e eu me vejo, naquela manhã de 16 de agôsto de 1934, a testemunhar, na sala da diretoria desta Faculdade, à imposição a um jovem bacharelando do capêlo de bacharel.

Já a êsse tempo havíeis publicado o vosso primeiro livro - O Estado Moderno, revelando a madureza de espírito de um moço de vinte e quatro anos incompletos. A vossa preparação humanística, por outro lado, vos propiciava o ensêjo de ensinar latim e psicologia em curso de preparatórios, de onde passastes a professor de Direito Comercial e Legislação Fiscal no Ateneu Graça Aranha; também prelecionastes Sociologia e História da Filosofia, no Instituto Paulista de Alta Cultura. 
A essa primeira produção do acadêmico seguiram-se logo após os primeiros trabalhos do advogado. Formas̃a da Política Burguêsa, O Capitalismo Internacional, Atualidades de um Mundo Antigo e Atualidades Brasileiras, são os novos degraus em que se assenta o vosso renome de publicista.

No mesmo ano em que vieram a lume os Fundamentos do Direito, tese de concurso com que ascendestes à cátedra que tanto enalteceis nesta Faculdade, também surgiu a Teoria do Direito $e$ do Estado, que vale em verdade como uma complementação daquela obra, na qual visastes trazer uma contribuição ao estudo da formação, da natureza e da validade da ordem jurídica positiva. Se é exato que o Direito preexiste à criação do Estado, sòmente com a formação do Estado é que se dá a definitiva consagração do Direito. Eis porque, citando Delos, em seu ensaio sôbre a teoria da instituição, no qual proclama que "as realidades juridicas encobrem fatos sociológicos: êstes são o "substractum", a substância interna dos fatos e das atividades jurídicas", assim conceituais o problema: “o juridico não é nada mais do que o social que recebeu uma forma, em virtude da intervenção da autoridade".

É em vossa dissertação de concurso que lançais as bases da vossa teoria tridimensional do Direito, que tanto relêvo daria ao vosso nome entre os juristas e filósofos contemporâneos. Fato, valor e norma constitui o derradeiro capítulo de vosso notável ensaio. O Direito não é "puro fato, nem pura norma, mas é o fato social na forma que lhe dá uma norma racionalmente promulgada por uma autoridade competente segundo uma ordem de valores", (p. 301/2). E, examinando a interpretação de Georges Aillet à lei dos três estados de Augusto Comte, assim concluis êsse capítulo e assim encerrais o vosso trabalho: “ .o Direito Natural de nossa época tem um cunho eminentemente realista, o que não quer dizer que não saiba levar em conta, quando preciso, o alto valor das especulações metafísicas. O que nos 
parece certo é que esta concepção corresponde ao desejo que as novas gerações sentem de reunir, em uma grande sintese, o real e o ideal, o fato, o valor e a norma", (p. 320).

Acredito que, nesse instante, a vossa doutrina ainda não havia atingido em vosso espírito a sua feição completa. Porque em vosso discurso de posse na Faculdade de Direito falais no "caráter bidimensional do Direito, que possui um "substractum sociológico", no qual se concretizam os valores de uma cultura, e, ao mesmo tempo, é "norma" que surge da necessidade de segurança na atualização dêsses valores". Só mais tarde é que o elemento intermediário se fixa em vossa teoria.

A doutrina que lançastes, da tridimensionalidade do Direito, vai ganhando terreno entre juristas e filósofos. A ela voltastes em outras oportunidades, dando-lhe o traço definitivo no Título $\mathrm{X}$ da vossa Filosofia do Direito. Foi ela discutida e exaltada em obras científicas, em revistas especializadas, em congresso internacionais. Recaséns Siches abre capitulos à parte em dois de seus livros para acolhê-la. Michel Villey coloca o vosso nome ao lado de Giorgio Del Vecchio, Kelsen, Dabin, Roubier, Cossio. Vossa Filosofia do Direito, traduzida para o italiano por Luigi Bagolini e G. Ricci, é apontada pelos maiores mestres como livro fundamental para o conhecimento da matéria.

Não seria possível, senhor Miguel Reale, fazer neste breve discurso a análise completa de vossa obra. Nem teria eu decerto a competência especializada que para tanto se requer. Fôrça é, todavia, referir aqui alguns de vossos trabalhos que, abordando facetas diversas do problema filosófico-jurídico, apresentam-se como desenvolvimento de vossa obra principal. Assim As três acepcões fundamentais da palavra Direito, a Concreção de fato, valor e norma no Direito Romano Clássico. Porque, em verdade, "os romanos não chegaram ao estudo dos princípios ou fundamentos do Direito senão depois de uma pluri-secular experiência jurídica. Durante os primeiros séculos, bastou-lhes o seu 
Direito particularista e próprio, o jus civile, explicado como um conjunto de preceitos estabelecidos "rebus ipsis dictantibus as necessitate exigente", ou seja, como um produto elaborado na medida das necessidades da vida e da lição da própria experiência. Para a compreensão dêsse ordenamento jurídico particularista, de cunho acentuadamente aristocrático e formalista, bastava a juris ratio. O que importava aos jurisconsultos romanos era o senso do Direito revelado como experiência concreta, a sábia determinação da razão dos preceitos, a prudente lição das normas vigentes, a hábil concatenação dos dispositivos particulares na configuração dos distintos institutos, em uma palavra, o trabalho conseqüente do jurisperito, operando com "gêneros" e "espécies" em função da realidade social diretamente vivida". (cf. Revista da Faculdade de Direito, 49/198).

E o que havíeis escrito muitos anos antes em vossa prova escrita do concurso de Filosofia do Direito, versando o tema que vos coube por sorteio, sôbre $O$ conceito de "ratio naturalis" entre os jurisconsultos romanos e Santo Tomás de Aquino. Sendo aquêles "juristas antes de mais nada, tiveram sempre as vistas voltadas para as questões postas pela prática e, nesse mister, se revelaram de uma precisão inexcedível, aplicando um método que com razão foi considerado quase que geométrico", (cf. Revista, cit., $38 / 107)$.

São magistrais as páginas que dedicastes à Teoria estimativa do Direito, a propósito do livro de Carlos Cossio. $\mathrm{E}$, escrevendo sôbre $O$ Contratualismo - Posição de Rousseau e de Kant, dais uma interpretação nítida do problema. "O contrato social é, em suma, para Kant mais do que para qualquer outro pensador, a condição sem a qual o homem não poderia realizar seu fim último". Em sua obra, tal é o vosso conceito, o contratualismo alcança a sua expressão máxima.

Como notas à margem do estudo de Clovis Bevilaqua a respeito d'A Doutrina de Kant no Brasil, traçais em dois 
artigos publicados na Revista da Faculdade de Direito, (42/51 e 43/113), um ensaio magistral.

Sustenta Clovis que as idéias de Kant "não foram das que influiram mais fortemente na marcha do pensamento brasileiro, exercendo apenas a ascendência própria das grandes correntes que no fundo do conhecimento revelam claridades novas", (Rev., 42/57). Rebateis essa conceituação, mostrando como "foi sob o signo das idéias de Kant que tiveram início os estudos jurídicos no Brasil". Lembrais a propósito o primoroso discurso proferido nesta Casa pelo professor Reynaldo Porchat, a 11 de agôsto de 1937, sôbre o Pensamento Filosófico no primeiro século da Academia e no qual o mestre eminentíssimo consagra um capítulo inteiro ao filósofo de Koenigsberg, "Rousseau proclamou a liberdade como a essência do homem, observa Hegel, a êste princípio foi a transição para a filosofia de Kant, da qual será o fundamento.

Sendo Avelar Brotero o primeiro professor de Direito Natural, é todavia com João Crispiniano Soares, mestre de Direito Romano, que as idéias filosóficas começam a penetrar nas Arcadas, com a divulgação dos principios da escola histórica, através os ensinamentos de Frederico Carlos de Savigny.

Surge, porém, com a Teoria Transcendental do Direito, de João Teodoro Xavier, em 1876, a pregação na cátedra dos princípios da escola racionalista pura de Emanuel Kant. Não se escraviza o mestre à doutrina Kantiana: antes, combate-a no que entende conter demasias. Põe de lado o compêndio de Vicente Ferrer, que orientava os estudos em Coimbra, dando na Faculdade uma clarinada nova no ensino da filosofia.

Sá e Benevides, que o sucede na cadeira de Direito Natural, em 1878, renega as doutrinas modernas, para se subordinar às diretrizes da escola teológica.

Inaugura-se em Brasílio Machado, em 1890, a cátedra de Filosofia do Direito. Passa o mestre logo após para a 
cadeira de Direito Comercial, assumindo a cátedra de Filosofia Pedro Augusto Carneiro Lessa, de quem já dissestes haver posto o pensamento filosófico-jurídico dêste Instituto "em dia com o que se processava nos domínios da cultura ocidental". E após breve passagem pela cadeira do professor João Pedro da Veiga Filho, assume a regência dessa disciplina João Brás de Oliveira Arruda, em 1910. Com Pedro Lessa e João Arruda os estudos da Filosofia do Direito assumiram em São Paulo feição verdadeiramente científica.

Sois dêsses dois mestres eminentíssimos o legítimo sucessor. Assumindo a cátedra de Filosofia do Direito aos trinta anos de idade, chegais a esta altura da vida, ainda bem moço, a uma projeção verdadeiramente notável entre os juristas de nosso país. $O$ vosso nome alcançou a maior admiração e respeito nos mais elevados centros da cultura ocidental. O relatório que vos indicou ao prêmio de ciências jurídicas, da Fundação Prêmio "Moinho Santista", assinalou com justeza que, "como invulgar estimulador e organizador da vida filosófica em escala nacional e internacional, como compreensivo historiador, evocando figuras e momentos olvidados do pensamento brasileiro, e sobretudo como autor de teoria reconhecidamente original sôbre a essência do Direito, valendo ao Brasil honrosa representação na história universal da filosofia contemporânea", também fazieis jús ao prêmio de Filosofia. Encarnais maravilhosamente, como se dava com Pedro Lessa, as peregrinas qualidades de jurista e de filósofo. E enquanto dizemos do primeiro ter sido um jurista-filósofo, de vós diremos, senhor Miguel Reale, que sois um filósofo-jurista.

Outros destaquem o vosso merecimento como advogado, como homem de letras, como orador exímio; coloquem no devido realce a atuação que exercestes como Reitor da Universidade, Secretário de Estado, Representante do Brasil na Conferência Internacional do Trabalho, em 1951. A mim me basta falar, embora em breves têrmos, de vossa obra como cultor do Direito e da Filosofia. 
Cumpre lembrar ainda, na vasta produção científica do vosso engenho privilegiado, o exame que fizestes da posição filosófica de João Mendes Júnior, no estudo que dedicastes à Escolástica e Praxismo em sua teoria do direito, (cf. Revista da Faculdade de Direito, 51/26). Assim como a revelação que nos trouxestes de haver a doutrina de Kant sido exposta pelo padre Diogo Antonio Feijó, em suas aulas de Lógica e Filosofia Moral, na cidade de Itú, na mesma época em que Victor Cousin "podia vangloriar-se de ser o primeiro a expôr de uma cátedra a doutrina de Kant em França", (cf. Revista cit., 45/331).

Muito teria ainda a dizer, senhor professor Miguel Reale, sôbre a intensa atividade intelectual que vindes exercendo desde os dias de vossa juventude. Sôbre o vosso merecimento como jurista e como filósofo, tudo foi dito e rememorado nas comissões do Prêmio "Moinho Santista", levando o Grande Juri, em que se representam as mais altas instituições da vida nacional, a sagrar-vos como o seu eleito.

Não encerrarei estas palavras, todavia, sem uma breve referência às duas últimas obras que publicastes: Parlamentarismo Brasileiro, em que compendiastes a conferência proferida sôbre a matéria na Câmara Municipal de São Paulo e os debates que a ela se seguiram, assim como Pluralismo e Liberdade, coletânea de preciosos ensaios em tôrno da liberdade e da democracia.

Mais uma vez evidenciastes que não viveis insulado na tôrre de vossas meditações filosóficas, nem sepultado entre os livros de vossa biblioteca, a perquirir os temas jurídicos de vossa predileção. Vindes para a agora, através da palavra e do livro, orientando as novas gerações quanto aos seus deveres para com a pátria.

Pluralismo e Liberdade foi obra que se editou no momento justo, em que a sociedade brasileira percebia estar vivendo instantes crepusculares, em que tais princípios como que perdiam a sua razão de ser. Compreendestes perfeitamente os perigos a que nos encontrávamos expostos. $E$ as palavras iniciais do vosso livro bem revelam as preocupa- 
ções que vos assaltavam: "Os tempos parecem pouco propícios ao debate dos temas fundamentais da liberdade, sobretudo da liberdade política, expressão imediata da liberdade moral, mas é razão a mais para a análise dos motivos que vão gerando, na consciência popular, a hedionda conviç̧̃̃o de que a perda da liberdade seja o preço inexorável da justiça social reclamada como valor mais urgente. $\mathrm{Na}$ realidade, se a liberdade política por si só não basta, também é indubitável que sem ela tudo se mostra precário e vacilante".

Para que a não percamos, contudo, é mister que nos mostremos dignos dela. Foi por isso que a sabedoria americana fêz gravar em pedra, no frontispício de um museu de Washington: The price of liberty is eternal vigilance. .

Filósofo e jurista, senhor professor Miguel Reale, não tendes olvidado a pregação da liberdade. Ainda por isso, mereceis o nosso reconhecimento.

A Fundação Prêmio "Moinho Santista", com a mercê que hoje vos outorga, homenageia em vós os juristas brasileiros, que têm em vossa pessoa um de seus mais altos representantes. E vos concita a prosseguirdes em vossa tarefa de estudioso do Direito, elevando cada vez mais, como o tendes feito até agora, o prestígio da nossa terra.

\section{Saudação do prof. dr. Alfredo Buzaid.}

Aos inúmeros títulos que galardoam a vossa fecunda existência, o de filósofo, o de mestre do direito e o de homem público, podeis ajuntar agora o de agraciado pelo prêmio Moinho Santista. Não postulastes tão alta mercê. Mas a Comissão de Juristas, integrada por professôres universitários de todo o país, apreciando o valor da contribuição original que destes para o progresso das ciências do espírito, indicou-vos o nome ao Grande Júri; e êste, que reúne o escol da intelectualidade brasileira, homologou-lhe 
o parecer, num expressivo reconhecimento aos méritos de vossa obra de renovação cultural.

Do regozijo da Congregação desta Faculdade, a que servis com entranhado amor e irrivalizável devotamento, não é preciso dizer-vos. Nos olhares de todos os vossos colegas transluz a alegria de aplaudir efusiva e entusiàsticamente a láurea que recebestes. Conforme o estilo dêste ato, compete a um dos professôres dirigir-vos uma saudação breve, moldada em linguagem lìdimamente acadêmica. Hesitei se devia obedecer à prescrição regimental. Um tal discurso, se em verdade condiz com as formalidades desta cerimônia, não tem contudo, a virtude de ser autêntico, porque falar de vós não é falar apenas de um homem no esplendor e no triunfo, mas sim do espírito de uma época, dos enseios de um povo na vibração romântica dos seus sonhos, da beleza quase heróica da radiosa alvorada brasileira. Em vez de falar de vós, julguei mais legítimo falar convosco, substituindo o monólogo solene, que exalta as sábias lições de filósofo, a variada e profunda erudição do jurista e a admirável coerência do homem público, pelo diálogo sincero, que nos irmana no ideal de um novo mundo, na pureza dos princípios cristãos e na fidelidade às instituições democráticas, de que vós sois incontestàvelmente um evangelista.

Filhos de uma geração atribulada, madrugamos para a vida, em 1930, numa hora de agitação universal. $O$ ano de 1930 é, na história do Brasil, um divisor de idéias, que marca o fim de uma era e o início de uma experiência política, social e econômica, quiçá a mais importante por que haveria de passar o país. A geração anterior se comprazia em escrever versos, romances, novelas e contos; freqüentava os cafés do Rio e os restaurantes de São Paulo, à maneira dos poetas franceses do século XIX; e dissipava o tempo em porfias literárias, muitas das quais eram inúteis ou estéreis, bem que ao gôsto daquela época despreocupada. Até então as lutas desencadeadas no território nacional ti- 
nham caráter antes político que social; eram encontros e desencontros de homens na conquista do poder.

A revolução de 1930 rasga, porém, novo horizonte, focalizando problemas sociais já pressentidos, mas ainda não sentidos em tôda plenitude pela consciência jurídica nacional. Foi justamente nesse período que entramos para a Faculdade de Direito, tomando conhecimento de problemas novos e angustiosos, que nos exigiam definição nítida num plano de idéias de valor universal. Começa aí, senhor Professor Miguel Reale, a vossa glória e o vosso fadário. Até 1934 a Faculdade de Direito é um laboratório de efervescências e inquietações. Nossas idéias políticas, sociais e econômicas assinalam as diretrizes fundamentais do pensamento brasileiro, que há de passar pelas mais diferentes vicissitudes. Os revolucionários de 1930 haviam esquecido a promessa de restituir à nação a soberania do auto-govêrno. Os paulistas sacudiram-nos num desafio, tomando armas e caminhando corajosamente para as trincheiras na mais surpreendente das afirmações de fé na democracia. Participamos dessa arrancada cívica, porque ela era o repto dos nossos pendores democráticos contra a perpetuação da ditadura. O regresso das frentes de combate trouxe-nos a convicção de que a derrota nas operações militares era apenas o prelúdio do triunfo na reconstitucionalização da Pátria.

A vossa formação nasceu aqui, sob as arcadas, nessa fase tumultuária de vida brasileira, em que vos afirmastes a um tempo filósofo, jurista e homem público. Dificilmente se pode dizer qual dêsses aspectos preponderou na vossa vida. O filósofo era um renovador do pensamento, que adejava os primeiros vôos. O jurista revelava a constante preocupação de compreender os supremos ideais de uma nova ordem jurídica, capaz de organizar a nação, resolverthe os problemas essenciais e salvar os direitos do homem. O político via as atualidades brasileiras no plano dos nossos problemas particulares. 
O filósofo completa o jurista e o político. Se fôsseis apenas filósofo, viveríeis num mundo de puras abstrações, sonhando, à maneira de Platão, uma República ideal e imaculada; se fôsseis apenas homem público, faltar-vos-ia o cabedal dos princípios fundamentais, que elevam a política, de arte de soluções fragamentárias e utilitaristas, ditadas pelas razões de conveniência, à condição de ciência moral normativa, cujo objeto é o govêrno da sociedade pelo Estado na realização do bem comum. O ponto de interseção entre o filósofo e o político está no jurista, que se não alheia das realidades sociais.

Que diferença profunda marca o encontro dessas duas gerações. A geração anterior a 1930 viveu um período de relativa paz, não tendo sido violentada por nenhuma grave perturbação social; a geração posterior adquire desde logo a consciência de que um papel decisivo lhe estava reservado num mundo conturbado em sua própria estrutura. Se a geração anterior pôde deleitar-se no cultivo das atividades literárias, a geração atual é dominada pela preocupação absorvente do ideal político e da renovação social.

Dessa radical transformação, que desencadeou uma crise ideológica sem precedentes na história do mundo, não somos meros espectadores senão protagonistas, que participam inexoràvelmente do processo revolucionário. É que, no entrechoque das correntes principais do pensamento, que separam o ocidente e o oriente em dois mundos irreconciliáveis, a ninguém assiste o direito de se encasular num ceticismo indiferente, quando a sorte da humanidade está em jôgo, pondo em risco um patrimônio de conquistas centenárias. A característica de nossa geração é a heroicidade de não poder ausentar-se na luta das idéias cristãs e democráticas, que banharam o berço de nossa nacionalidade.

As vossas intuições filosóficas e jurídicas, senhor Professor Miguel Reale, repontam no lustro de 1934-1939. Daí por diante o vosso espírito, permanentemente inquieto, dilata os horizontes dos conhecimentos, ordena as leis do pensamento, plasma a forma da linguagem e sistematiza a 
investigação científica, passando a ser, pela fecundidade e eminência da produção, o chefe incontrastável da nova escola filosófico-jurídica nacional.

Dois caracteres assinalam a vossa obra: a coerência na sistemática e o progresso na evolução científica. Quando, aos vinte e quatro anos de idade, publicastes o Estado Moderno, já dizíeis no prefácio: "Éste livro exprime a vontade firme de teorizar a vida e de viver a teoria na unidade indissolúvel do pensamento e da ação". Êste conceito encerra o valor de uma mensagem. Ainda em 1934, em outro livro Formação da Política Burguêsa, destinado a completar o Estado Moderno, vossa indagação, bem que reconhecendo algo de descontínuo na história, ressalta, através dos tempos, a identidade essencial da natureza humana (Formação da Política Burguêsa, p. 9), que é um elemento primordial de valor constante.

Que admirável conceito! As criaturas são, na verdade, sempre iguais; a humanidade é que se diferencia. Quem busca a confirmação desta verdade, não há de surpreender-se que a história se repete mais através de analogias que de contrastes. A vossa perspectiva de historiador não se detém no passado como um dado imóvel. "Muda-se a posição do observador no tempo", dizieis, "e eis que uma nova luz se projeta sôbre os fatos, revelando aspectos desconhecidos, detalhes impressionantes". (Formação da Política Burguêsa, p. 11).

Percebendo que estamos no limiar de uma nova idade e de uma nova cultura, afirmais que o passado sobrevive no presente através de inelutável condicionalismo histórico; assim escrevestes que "a civilização repousa sôbre uma crença exclusiva em uma dada atitude do espírito e é um complexo de modos de ser, de pensar e de agir que domina os homens (op. cit., p. 11).

Realmente, o espírito de um povo reside nas suas leis, nos seus costumes, nas suas instituições, nos seus sentimentos, em certo destino, superior às formas de govêrno. O que 
lhe dá a grandeza é, porém, a sua consciência religiosa, virtude singular que não surge senão nos povos que crêem na vida transcendental do homem. Bem compreendestes êste fenômeno em outro livro, Atualidades de um Mundo Antigo, em que traçastes, com mão de mestre, as linhas fundamentais de uma concepção integral da história. "A religiñ̃o", escrevestes, "a angústia eterna do coração humano en procura de uma explicação suprema para a vida, o sentimento de que nós não somos tudo, a consciência de que somos mais que o caniço frágil que se dobra ao vento, a religião, não como mero fato social ou como instituição do culto, mas como fôrça espiritual, a religião não penetra no âmago da história? O problema do destino humano é $\mathrm{r}^{r}$ ligioso antes de ser filosófico" (Atualidades de um Mundo Antigo, p. 20 e segs.).

Completa-se essa admirável fase da vossa atividade científica com a publicação de Fundamentos do Direito e Teoria do Direito e do Estado. Nestas duas obras, escritas há vinte e quatro anos, lançastes as bases definitivas das principais idéias, que verelam a vossa contribuição original no pensamento filosófico-jurídico. A teoria tridimensional do Direito e do Estado, caracterizada pelo fato, valor e norma, três aspectos de uma realidade única, segue uma evolução gradual, passando de categorias genéricas a categorias específicas, que se fundem numa unidade substancial, com caráter dinâmico e concreto (Teoria do Direito $e$ do Estado, 2. ${ }^{a}$ ed., p. 11; Aspectos da Teoria Tridimensional do Direito, p. 9).

Abre-se agora a segunda fase da vossa vida, que conta já com quase um quarto de século de dedicação aos estudos especulativos, de infatigável atividade cultural e de incessante produção científica. Fundastes o Instituto Brasileiro de Filosofia, cenáculo augusto de uma plêiade de estudiosos que vivem na mais alta especulação do pensamento; pusestes a serviço dêle a Revista Brasileira de Filosofia autêntico veículo de idéias, que agasalha em suas páginas tôdas as 
tendências doutrinárias, desde que os seus intérpretes se inspirem em uma compreensão séria dos valores fundamentais da ciência; formastes uma escola de dedicados pesquisadores, que se estreitam em profunda afinidade com o mestre pela identidade do método e pelo amor à sabedoria.

Ao longo dêstes cinco lustros difundistes e aperfeiçoastes as vossas idéias filosóficas, lançando o Curso de Filosofia do Direito, já traduzido para o italiano por Bagolini e Ricci; devassastes aspectos olvidados do pensamento brasileiro no período colonial e imperial, analisando as obras de Brotero e Krause, a doutrina filosófico-processual de João Mendes Junior e o positivismo de Pedro Lessa.

Mas de todos os vossos trabalhos, aquêle em que reluz mais nitidamente o vosso ideal, em que palpita mais eloqüente a fôrça do vosso pensamento e em que o homem se identifica com o pensador é Pluralismo e Liberdade. Neste livro, jóia da literatura nacional, definistes o problema que sempre torturou a vossa alma inquieta: a relação entre o princípio da autoridade e a garantia da liberdade. A publicação dêste livro coincide com as horas turbulentas, que precederam ao triunfo da revolução de março. Vistes que o país era arrastado à mais ousada aventura política, tendente a destruir as instituições nacionais e substituí-las por uma ditadura marxista, preparada com técnica e precisão. $\mathrm{O}$ vosso livro sai à luz como uma advertência aos intelectuais, mostrando que era preciso preservar a liberdade, porque estávamos ameaçados de perdê-la no dia seguinte. $\mathrm{E}$ depois de perdê-la, seriam baldadas tôdas as esperanças de recuperá-la, porque a experiência de muitos povos assinalou que, onde se implanta o marxismo-leninista, o único partido que governa a sociedade mata os apóstolos da liberdade para fazer viver uma ditadura mono-partidária. Vaticinastes, como um profeta, o temporal que ia desabar sôbre a Pátria. Essa intuição, tão própria dos poetas, que desvendam os horizontes esfumados, me lembra um episódio ocorrido na vida de Goethe. 
Conta Eckermann que se dirigia, numa tarde, para Erfurht, quando percebeu que, na estrada, lado a lado, caminhava também um homem de idade. Apenas começaram a conversar, o diálogo recai sôbre a pessoa de Goethe. Perguntou Eckermann ao viandante se o conhecia.

"Conheço-o", respondeu com satisfação. "Fui seu criado de quarto quase vinte anos".

Pediu-lhe Eckermann que lhe contasse alguma coisa da juventude de Goethe. E o antigo criado de quarto, depois de dizer que Goethe se ocupava com problemas de ciência e investigação da natureza, narrou o seguinte fato:

"Certa feita chamou-me Goethe a horas mortas da noite; ao entrar no quarto, observei que Goethe deslocara o divã de um canto para junto da janela, donde contemplava o céu.

"Não vistes nada no céu", indagou Goethe.

Como nada respondesse, Goethe disse-lhe:

"Então corra à guarda e pergunte à sentinela se viu alguma coisa".

O criado cumpriu a determinação e trouxe a resposta negativa, encontrando Goethe, debruçado à janela, a observar o céu.

"Ouve" disse-lhe Goethe, "estamos num momento crítico: há um tremor de terra ou vamos tê-lo em breve".

O céu estava coberto de nuvens, mas calmo embora abafado. Não circulava nenhuma corrente de ar.

$O$ criado de quarto, embora nada tivesse visto, acreditou no patrão. No dia seguinte, porém, quando o fato era narrado na côrte, certa data segredou ao ouvido de outra:

"Vejo! Goethe está a brincar".

Dias depois, chegando a mala postal, confirmou-se a notícia de que, naquela noite, uma parte da cidade de Messina tinha sido destruída por um tremor de terra (Eckermann, Gesprache mit Goethe, p. 46).

Os poetas e os filósofos são assim. Vêm o que os outros não vêm. Devassam os enigmas insondáveis. E tentam 
explicar, com certa emoção cabalística, os mistérios do mundo.

Há trinta anos, senhor Professor Miguel Reale, à maneira de Goethe, previstes que um grave tremor de terra haveria de sacudir o país, porque os homens públicos preferiram antes afastar o perigo de uma convulsão social do que enfrentá-lo com coragem; porque os políticos em vez de formarem a opinião pública à luz de uma consciência democrática e de amor à liberdade, se entregaram a disputa de cargos, mediocrisando-se em competições pessoais; porque, finalmente, se alhearam da política como ciência para dela se servirem como mera arte de rivalidades pessoais.

A vossa advertência ecoou, porém, no país, desde a praça pública até os mais conspícuos congressos de filosofia; através de livros e de artigos de doutrina; pela imprensa, peỉo rádio e pela televisão; em todos os lugares, onde se levantou uma tribuna para difundir o pensamento de renovação nacional.

Bemaventurado, o país que ainda possui apóstolos de vossa estatura!

\section{Saudação do bacharelando Celso Lafer.}

Saudamos V. Excia. e o homenageamos pela justíssima outorga do prêmio Moinho Santista no campo das ciências jurídicas. O prêmio é o reconhecimento do alto valor de tôda uma obra e esta nos coloca na paradoxal situação de, ao prestar-lhe uma homenagem, não estarmos senão a retribuir, num momento, a homenagem permanente que a obra de V Excia. presta ao nosso espírito. Ao paradoxo deve somar-se o embaraço em que nos achamos. A praxe manda que, em homenagem como esta, sejam mencionados os pontos culminantes do pensamento do homenageado. Confessâmo-nos, porém, embaraçados para obedecer à praxe, pela impossibilidade de abordar tôda sua obra, 
mesmo em breve sintese. Tomamos, porisso, a decisão do nos cingirmos a uma formulação que se encontra em um de seus livros juvenis, mas que o tem acompanhado durante tôda a sua vida, conforme V. Excia. tem declarado reiteradas vêzes. Diz V. Excia.: “É preciso teorizar a vida e viver a teoria numa unidade indissolúvel de pensamento e de ação". Esta colocação de capital importância reflete inclusive a emergência do advogado na vida pública da sociedade contemporânea. De fato a democracia parte da conclusão sociológica — de que uma sociedade complexa é necessàriamente diversificada e do imperativo ético de que é justo que os vários grupos que a compõem tenham os seus interêsses representados e respeitados. Ora, o macrocosmos da vida política repete de certa forma o microcosmos do processo onde também encontramos partes e interêsses cuja existência legitima e condiciona a vida jurídica. Assim, a própria formação profissional do advogado é talhada para a ação. Como conciliar a vida de pensamento com as contradições inevitáveis da ação é a próxima pergunta que devemos propor. A resposta nos é dada por Max Weber num estudo onde demonstra que se o sábio não atuante pode limitar-se a uma ética de convicção o sábio participante deve acrescer a esta ética de convicção uma ética de responsabilidade. Mas de que modo medir a responsabilidade? Ascarelli indica os dois caminhos do direito, não através de análises de juristas, mas de figuras literárias, a provar que o direito não é uma árida ciência, mas a própria vida social. $O$ primeiro caminho, simboliza-o Antigone, morrendo em nome de uma lei que julgava superior à lei positiva, mas provocando a mudança desta. Temos aqui a ruptura total com uma determinada ordem, através de uma reforma ou de uma revolução que positiva uma nova ordem em normas sancionadoras que serão, por seu turno, superadas. O segundo caminho é simbolizado por outra figura, não mais do teatro grego mas de Shakespeare: Pórcia. Pórcia não negou que 
Shylock tivesse direito a um pedaço do corpo de Antônio. Aceitou o pacto, mas interpretando-o, negou a Shylock o direito de derramar uma só gota de sangue de Antônio, anulando, pois, o pacto antes celebrado. Portanto, Porcia não nega a validez da ordem jurídica. Interpreta-a, porém, e interpretando-a redu-la a nada e conseqüentemente a supera. Cremos caro mestre prof. Miguel Reale que Porcia tem sido a sua companheira se bem que V. Excia. não tenha recusado algumas aventuras com Antigone. Mas seja através de um seja através de outro caminho, ensina Ascarelli: "O jurista tomará a História como seu ponto de partida e tornará a olhar a História como seu ponto de chegada". E é êste exatamente caro mestre o seu ponto-de-vista, já que "a ação é a energia dirigida para algo que é sempre um valor" e uma axiologia a histórica não tem sentido pois "é na história e pela história que se aperfeiçoa o conhecimento do mundo dos valores". Prosseguindo na caminhada pelo seu pensamento, encontramos nos valores fundantes da democracia a referência de uma ética de responsabilidade. A democracia deve ser vista como um "processo histórico incessante de integração de valores de convivência" que V. Excia. discrimina da seguinte forma: 1) o legado da Grécia ou seja a liberdade de pensar como pluralidade de pensar. Dêle conclui V. Excia.: "é o primeiro dos pilares da ideologia democrática, aquêle que tornou possível de certa maneira, o revelar-se dos outros, ficando dêste modo, claro que, onde quer que falte ao homem a faculdade de ser fiel a si mesmo, ao próprio pensamento; onde quer que haja pensamento único, impôsto como verdade transpessoal e definitiva; onde quer que haja órgãos de ortodoxia política, a determinar autocríticas que culminam em atos de submissão aos mentores do ideário oficial, pode haver tudo, menos democracia". 2) o legado de Roma ou seja a consciência dos valores autônomos do Direito para que fique "afastada a idéia do arbítrio que representa uma ruptura na ordem racional, um hiato na harmonia dos valores de convivência". 
3) o legado do cristianismo ou o reconhecimento da igualdade da natureza humana. 4) o legado do liberalismo ou seja a noção de "Estado de Direito" "desde que a palavra "direito" deixe de significar um conjunto de preceitos protetores de interêsses para ser o bem social normativamente ordenado, o direito, em suma, como experiência concreta que pode se expressar em leis mas que com as leis não se confunde". 5) o legado do socialismo ou seja "uma compreensão mais concreta, ... existencial da idéia de igualdade entendida como direito reconhecido a cada homem de participar do "bem-estar social" dos bens que a espécie humana vai acumulando através do tempo como resultado do esfôrço conjunto das elites e das massas anônimas".

Eminente mestre prof. Miguel Reale, êste parece ser o sentido profundo da relação feita por V. Excia. entre logos c pragma. Procuramos captar o seu conteúdo de verdade e justiça que, no dizer de sábio ensinamento talmúdico, são o sustentáculo do mundo. Ao concluirmos, só nos resta dizer que, diante das superiores qualidades de espírito de V. Excia. não temos outra alternativa que não seja a admiração. Receba portanto prof. Miguel Reale o preito de admiração de seus alunos, e receba-o envolvido pelo calor da amizade que lhe dedicamos.

\section{Discurso do Professor Miguel Reale Agradecendo o "Prêmio Moinho Santista".}

Permiti, esta noite, quando tão alto me eleva a vossa generosidade, recordar um episódio de minha vida, que penso ter sido o instante germinal de uma carreira que houvesteis por bem considerar fecunda.

Era uma tarde chuvosa de outubro, já lá vão 35 anos. Estava eu do outro lado do Largo de São Francisco, aguardando condução para retôrno ao lar, quando meus olhos se pousaram demoradamente sôbre a fachada do antigo 
convento de taipas. Era o mesmo casarão visto e admirado tantas vêzes, mas, naquele instante as paredes vetustas como que me falaram com o sortilégio de um templo grego desvelando o futuro.

Adolescente, prematuramente acordado para as preocupações e as angústias da sociedade contemporânea, como tem acontecido às gerações dêste século, que vertiginosamente passam da infância para a juventude, - estava então vivendo dias de profunda perplexidade. Chegara a hora de escolher um caminho, com sacrifício de mil outros possíveis. Que digo? Chegara o momento decisivo na vida de um jovem, o de encontrar o único caminho possível, aquêle que realiza a sua vocação como desdobramento natural de tendências e projeção espontânea da própria personalidade.

Filho, neto e bisneto de médicos, com uma longa e gloriosa tradição familiar a serviço do Esculápio, já me sentia preparado para afrontar os exames vestibulares de medicina, mas meu coração continuava inquieto. Interessavam-me, sim, os problemas da vida, mas não na alternativa permanente da saúde e da doença, na vivência quotidiana do nascimento e da morte, nesse empenho de salvação biológica que marca a dignidade e a beleza da profissão de Hipócrates.

A vida que verdadeiramente me encantava e atraía era a vida do todo social, a existência coletiva com suas alegrias e seus desesperos, a "convivência humana", nos infinitos enlaces de esperanças e desenganos. Foi o que percebi aquela tarde, ao sentir-me chamado a ingressar nesta Casa. Tudo o que até então se ocultara nos refôlhos de minha alma, a tensão para o social e o coletivo, que me arrastava a discussões intermináveis com a confiança arrogante e precipitada tão natural nos moços, tudo o que latejava em meu eu profundo, aflorou repentinamente, na plena consciência de meu destino. 
E, desde aquêle instante, as Arcadas se tornaram a minha morada espiritual e, como sói acontecer àqueles que têm a ventura de aqui entrar, converteu-se em minha eterna namorada. Morada, à qual a nacionalidade se volve sempre confiante no fragor das intempéries; cerne de tradição e de perseverança no trabalho; fio condutor na continuidade essencial da história pátria. E namorada, como estímulo à aventura, desafio à autoconsciência, convite ao pensar autônomo e motivo renovador de poesia e devaneio.

a esta Casa, portanto, que estais premiando, que ela é uma lição viva de direito, do direito que se não cristaliza em ouropéis formais, nem se dissipa nas névoas de um querer quimérico, mas se embebe de exigências vitais; do direito que não é forma estrínseca da vida, mas a vida mesma na sintese normativa de fatos e valores, da realidade e do ideal.

Assim fluem os anos nesta Faculdade, entre o direito c a poesia e, quando cuidamos estar servindo à segunda para melhor conquistar o primeiro, o que ocorre é que ambos se integram em nossa personalidade, para que as regras jurídicas não assumam jamais a rigidez dos comandos, mas guardem sempre o cálido palpitar do amor que abre caminho à revelação do próximo.

Foi a polaridade existente entre o que somos e o que devemos ser; foi a verificação da ambivalência do ser humano, que assim como não é redutível a um simples sistema harmônico de ossos e de órgãos, também não flutua na evanescência das formas puras, por ser tudo isto na tensão de sua finitude existencial; foi, em suma, a compreensão da pessoa humana como valor-fonte de todos os valores e pedra de toque da legitimidade dos governos que me levou, paulatinamente, a conceber a "teoria tridimensional do direito", que antes de mais nada, marca uma exigência de totalidade e de concreção, a fim de que o filósofo do direito deixe de corresponder à imagem de um pobre hermafrodita, indeciso entre o canto de sereia das 
¿dealidades transcendentes e a sedução renovada dos infinitos desempenhos da vida.

Mais do que nunca se torna indispensável ao jurista não se transviar no labirinto dos fatos sociais, com perda do sentido unitário de sua tarefa humanística. Tal diretriz não será, todavia, exequível sem um mínimo de Filosofia do Direito, máxime numa época marcada por violentas transmutações nas categorias e tábuas de referência do convivio humano, e num país como o nosso, que está vivendo o momento decisivo de sua história, mal superado o pesadelo das agitações infecundas fomentadas por falsos pregadores de justiça social. Mister é, pois, que os juristas descortinem os amplos horizontes das aspirações populares, participando criadoramente da obra de interpretação serena e objetiva de nós mesmos, graças à sondagem até às raizes de nossa "condição humana" e de nossa "condição nacional"

Talvez resida aí a razão do prêmio com que me distinguis, fico eu a conjeturar, levado pelo hábito de indagar sempre das causas primeiras dos atos humanos. Sim, se algo me parece válido em minha experiência de jurista é o propósito de fidelidade às fontes primordiais de nossa tradição jurídica, que tem sabido fincar os pés nas infraestruturas da positividade, apegando-se aos fatos com as cautelas dos velhos praxistas, para melhor poder projetar a cabeça confiante à altura dos valores ideais.

É êsse mesmo amor concomitante pela realidade e pelo ideal que leva os homens de emprêsa, da alta categoria dos que integram o "Moinho Santista", a superar o âmbito às vêzes asfixiante do imediatismo econômico, para artìsticamente compor novas unidades de produção e de trabalho do mais alto alcance social, e a ter olhos também para apreciar as realizações culturais mais desinteressadas, os frutos das pesquisas que perfumam as intenções dos estudiosos em luta com a transitoriedade da existência. 
É indispensável que nos compreendamos, nós que servimos à economia e à justiça, pois esta pouco ou nada valerá como simples medida formal de igualdade, se o conteúdo do econômico não a tornar real e efetiva, de tal modo que a igualdade perante a lei passe a significar sempre igualdade perante a vida e a cultura, de conformidade com o Estado de Direito concretamente reclamado pela democracia atual, que é menos um regime do que o estágio histórico a que se elevam as sociedades através de sua intransferivel e pertinaz experiência do pluralismo das convicções e das iniciativas em uma comunhão de liberdade.

Em minha vida, como advogado ou professor, como político ou cultor das idéias, tenho procurado me manter fiel a essas perspectivas, sempre inconformado com a legalidade estrita ou com as formas ilusórias de justiça, o que me tem valido a incompreensão dos mediocres, pois o que importa é estarmos convictos de que o direito não é uma roupagem cortada ao talante dos rabiscadores de figurinos sociais, nem talhada às pressas sob o látego da violência ou composta pelas artimanhas da astúcia, por ser a forma que a sociedade vai por si e para si mesma modelando por fôrça de intrínsecas virtudes, sendo, assim, inseparável do processo de seu autorevelar-se.

São estas as palavras que vos posso dizer, ao sentir multiplicada a minha alegria pelas formosas orações proferidas por dois eminentes colegas, Ernesto de Morais Leme e Alfredo Buzaid. O primeiro, com a sua personalidade de escol, exemplarmente dedicado ao culto do direito e das letras, liga-me à geração de meus antigos mestres, a figuras magníficas como as de Francisco Morato, Braz de Souza Arruda, Gabriel de Rezende Filho, Waldemar Martins Ferreira, Jorge Americano, Vicente Ráo, Antonio Ferreira de Almeida Júnior e Honório Monteiro. A lembrança de Waldemar Ferreira, o primeiro jurista laureado pela "Fundação Moinho Santista", suscita-me um profundo sentimento, misto de saudade, de admiração e de responsabi- 
lidade, dando-me a nítida impressão de que o tempo vai carinhosamente interligando os fios da continuidade histórica, à medida que dedilha os momentos da vida. Oxalá possa esta recordação me valer como estímulo para prosseguir na jornada, guiado pelo exemplo daquele sempre jovem e incansável lidador!

Alfredo Buzaid é o companheiro dos bancos acadêmicos, de caminhadas por tôdas as direções do espírito. Somos irmãos nesta Academia, e, de mãos dadas, temos sonhado, pensado, construído, examinando-nos mùtuamente, a exigir um do outro o pagamento de uma promessa jamais formulada, mas implícita no teor de nossas conversas e no brilho esperançoso de nosso olhar de moços.

É o mesmo compromisso que renovo neste instante, perante esta assistência culta e amiga, com os olhos da inteligência voltados para os mestres insignes que integraram o Grande Juri e as Comissões Especiais, esperando poder compensar as demasias de sua decisão generosa, com novos estudos, novas pesquisas, novos empenhos, se a tanto amor bastar tão curta vida. 